\title{
Enhancing Helping Behavior: An Integrative Framework for Promotion Planning
}

Charitable organizations play a vital role in our society, as is evidenced by their enormous economic and social impact. Yet, for many of them, soliciting adequate resources to carry out their mandates is a continuing struggle. Confronted with a growing need for their services, fierce competition from other charities, and shrinking support from government agencies, charities may turn to marketers for help in developing effective promotional strategies. Unfortunately, marketing literature is unable to provide meaningful guidance because scant research attention has hampered a fuller understanding of why people help. The authors integrate relevant research in marketing, economics, sociology, and social psychology to advance theoretical understanding of helping behavior. They develop research propositions regarding specific promotional strategies that charitable organizations can employ to elicit help.

$\mathbf{T}$ he charitable impulse - reaching out to help another in need-is recognized as a universal human value. Yet, the economic and social impact of helping behavior is frequently overlooked. From an economic standpoint, helping is big business. In 1993, for example, Americans donated approximately $\$ 103$ billion to charitable causes (American Association of Fund-Raising Counsel 1994). From a social standpoint, these contributions enable charities to be socially responsive, by delivering services that are not adequately provided by either business or government (Kotler 1979).

Eliciting help for charity has never been an easy task. Nearly two decades ago, Rothschild (1979) alerted marketers to the difficulties in trying 0to sell "brotherhood" as they would soap. Specifically, selling soap-or other forprofit goods and services-involves stressing the value directly received by customers in return for their dollars. In contrast, selling "brotherhood" involves charities asking people to donate some resource (e.g., time, money, blood) with little or no commensurate reward in return. Although social marketing has always been challenging (Bloom and Novelli 1981), the current environment makes eliciting help especially daunting. Charities today must grapple with a growing need for their services, shrinking government support for their causes, and fierce competition with other charities. It is becoming more critical-and more difficult-for charities to elicit help from individual donors.

Neeli Bendapudi is Assistant Professor of Marketing, Texas A\&M University. Surendra N. Singh is Professor of Marketing and the Samuel Roberts Noble Foundation Chair in Marketing Strategy, Oklahoma State University. Venkat Bendapudi is a doctoral candidate, University of Kansas. The second author was at the University of Kansas when a significant portion of this paper was completed. The authors thank T. Ramesh Dutta, John Lastovicka, Howard Marmorstein, Peter Reingen, Michael Rothschild, three anonymous $J M$ reviewers, and the editor for their positive feedback and helpful suggestions on previous versions of this article.
To succeed in such an environment, a charity must rely on an effective promotional strategy: a controlled, integrated communications program to present itself and its services to prospective donors (Engel, Warshaw, and Kinnear 1994). Unfortunately, marketing literature, which is rich in research and theorizes about promoting for-profit products and services, offers little guidance to charities on how to promote helping. This neglect is puzzling given marketing scholars' characterizations of helping behavior as "crucially important ... and virtually undescribed" (Sherry 1983, p. 157), and "disjointed and void of theoretical underpinnings" (Burnett and Wood 1988, p. 2). Because of this gap in current knowledge, we seek to develop a better understanding of helping behavior, which in turn is used to suggest promotional strategies for charities. The article is organized as follows. We begin with an overview of the construct of helping behavior and review the research in marketing in this area. Next, we draw on the research in different discif ines, such as economics (e.g., agency theory, strategic altruism), sociology (e.g., normative influences, social comparison), and psychology (e.g., social impact theory, reactance theory) to identify factors that affect helping behavior. A discussion of the donor's helping decision process follows. At each step of the process, we explore how specific aspects of the charity's promotion may affect the helping decision. These interventions are presented as testable propositions. Finally, we address theoretical and practical implications and directions for further research.

\section{People's Helping Behavior Toward Charitable Organizations}

\section{Definition and Literature Review}

Helping behavior defined. Helping behavior may take many forms, from the trivial (giving directions to a stranger 
who is lost) to the magnificent (risking your life to save a drowning victim). It may involve one person helping another or a person helping through an intermediary organization (e.g., making a donation to the Red Cross). Organizations also help in both fashions: by directly aiding the needy (a church group adopting a needy family) or through an intermediary organization (e.g., corporate philanthropy, causerelated marketing; Varadarajan and Menon 1988). We focus on people helping the needy through intermediary charitable organizations.

But what constitutes help? The answer appears to vary across disciplines. Economists (e.g., Margolis 1982) focus on the consequences to the helper: Behavior is deemed "helping" only if the costs of the behavior exceed the benefits; that is, there is some sacrifice involved. Sociologists (Piliavin and Charng 1990) and psychologists (see Krebs and Miller 1985) focus on the motives behind the help: Is the motive to enhance the welfare of the needy (altruistic motive) or is it to somehow enhance a person's own welfare (egoistic motive)? The marketing discipline appears to focus on consequences to the help recipient-behavior is deemed helping when it enhances the recipient's welfare. Hence, donating time, money, blood, body parts, and so on are all deemed helping behavior. Despite these differences, there is a growing consensus that to understand helping behavior, it is important to understand all of these facets: the consequences to the recipient and the helper and the motives for providing help (Simon 1993). From the perspective of charitable organizations, the following definition of helping behavior seems appropriate: behavior that enhances the welfare of a needy other, by providing aid or benefit, usually with little or no commensurate reward in return.

\section{People Helping Through Charitable Organizations: A Review of Marketing Literature}

In Table 1, we provide an overview of the literature on helping behavior in leading marketing journals for over the past 20 years. ${ }^{1}$ One striking fact is the paucity of marketing stud-

IA computerized search was undertaken of the following journals from 1971 onwards: Journal of Advertising, Journal of Advertising Research, Journal of Consumer Policy, Journal of Consumer Research, Journal of Macromarketing, Journal of Marketing, Journal of Marketing Research, Journal of Professional Services Marketing, and Journal of Public Policy \& Marketing. In addition, all marketing journals from the year 1987 were included.

TABLE 1

Marketing Studies Dealing With Helping

\begin{tabular}{lll}
\hline Study & Type of Helping & Focus \\
\hline $\begin{array}{c}\text { Pessemier, Beamon, } \\
\text { and Hanssen (1977) }\end{array}$ & $\begin{array}{c}\text { Intention to donate } \\
\text { body parts (survey) }\end{array}$ & Donor characteristi \\
Reingen (1978) & $\begin{array}{c}\text { Face-to-face funds } \\
\text { donation }\end{array}$ & Size of request
\end{tabular}

Mindak and Bybee (1979)

Burnett (1981)

Burnkrant and Page (1982)

Soukop (1983)

Blockner and colleagues (1984)

Moore, Beardon, and Teel (1985)

Danko and Stanley, (1986)
Case study of March of Dimes

Blood donors and nondonors (survey)

Behavioral intentions in blood donations

Markov analysis

Face-to-face and telephone funds donation

Panel and laboratory studies of advertisement evaluations

High-income households' donations (survey)
Application of marketing principles

Donor characteristics

Type of request

Donor mailing lists

Size of request

Type of request. Beneficiary portrayal

Donor characteristics
Findings

Significant demographic and psychographic differences exist between those who are willing and those who are not willing to donate body parts.

Insignificant differences between foot-in-thedoor (FID) and door-in-the-face (DIF), with or without adding even-a-penny-will-help. All of these more effective than the control (request only) condition.

Applying target marketing, segmentation, marketing audit, and so on increased the funds received.

Significant differences exist between donors and nondonors on demographic and attitudinal variables.

Tests Fishbein's behavioral intention model. Both attitudinal and normative influences found to affect behavioral intentions.

High costs of fund-raising justified in attracting new donors.

Legitimization effective for differing suggested amounts and face-to-face as well as telephone contacts.

Labeling was effective and dependency claims were ineffective.

Significant differences exist between heavy and light donors on select demographic variables. 
Fern, Monroe, and Avila (1986)

Riecken and Yavas (1986)

Fraser, Hite, and Sauer (1988)

Dawson (1988)

La Tour and Manrai (1989)

Guy and Patton (1989)

Schlegelmilch Tannin (1989)

Allen and Maddox

(1990)

Harvey (1990)

Barr, Dave and Amin (1991)

Horton (1991)

Meyers-Levy and Maheswaran (1992)

Yavas, Riecken and Babakus (1993)

Allen and Butler (1993)

Bagozzi and Moore (1994)

Cermak, File, and Prince (1994)

Broadbridge and Horne (1994)

Schibrowsky and

Peltier (1995)

Type of Helping

Metanalysis of size of request studies

Size of request. FID and DIF

Donations to nonprofit
organizations

Face-to-face funds donation

Monetary donations and volunteering

Field experiments on blood donations

Conceptual framework

Survey of donations

Blood donations

Benefit segmentation

Attitudes toward one charitable organization
Conceptual-Organ donation

Donation to Save the Children

\section{Monetary donations and intentions to donate}

\section{Blood donation} intention

Public service advertisement

Benefit segmentation

Volunteering for charity retail stores

Field experiment on fund-raising
Opinion leaders and recipients

Size of request

Survey of motives for giving and volunteering

Type of request

Motivation for helping/ process

Type of request

Donor perceptions and awareness of blood donations

Donor characteristics

Survey of awareness and perception

Type of request

Type of request-timing of aversive negative outcome

Perceived risk (likelihood of loss and importance of loss)

Donor knowledge and risk perception

Type of request. Emotional appeal

Major or wealthy donor market

Demographics and motivation

Size of request
Findings

FID is effective when initial behavior is performed. DIF is effective when there is less delay between requests and the requests are made by the same requestor.

Greater proportion of opinion leaders than recipients donated to nonprofit organizations (self-reports).

Large anchor point effective to raise size of donations. Legitimization effective to raise rate of compliance.

Reciprocity and income motives predict giving as did household assets and age. Volunteers not higher on career motive than others.

Interaction of informative and normative requests more effective in generating blood donations than either one singly.

Altruistic motive for helping; internal and external mitigating factors.

People who donate in street collection, doorto-door, and so on-differ in demographic characteristics.

Three of four clusters of blood donors exhibited skepticism regarding blood donation, misinformation and uncertainties.

Demographic and psychographic correlates exist for donor segments.

Identified unmet needs by United Way of Horry County; low awareness in community of services offered by the organization.

Low involvement media to get attention. High involvement media later in decision process.

More intent to donate, counterfactual thoughts with short (versus long) time lag for low-involvement ; no difference for highly involved.

Perceived risk was not a good predictor of donation behavior; however, it improves prediction when used in conjunction with demographic variables.

Knowledge not inversely related to risk; may accentuate risk. Perceived risk inversely related to blood donations.

Empathic emotional responses elicited greater willingness to help. Empathy was greater in the strong versus the weak emotional advertisement.

Wealthy donors classified into four segments on demographic and psychographic variables.

Majority were white women, over 55, married or widowed. Reasons were affiliation with charity not experience with retailing.

The size of the request affected the percentage of givers and the size of giving. 
ies in this area; of the several thousand studies published, only 27 , or less than $.5 \%$, deal with helping. A similar pattern holds for conference proceedings as well. Over the past 10 years, on average, less than $1.5 \%$ of the articles in the proceedings of the American Marketing Association and the Association for Consumer Research deal with helping geared toward charities.

The few studies that have examined helping behavior have focused on select aspects of the charitable organization's solicitation strategy. For example, 5 of the 27 studies reported in Table 1 deal with the amount of donation requested. The type of request (e.g., whether labels such as "helpful" are used) is the focus of 7 studies. Although the attention to these issues is well deserved, the literature has not adequately addressed other equally important issues, such as social norms for helping and donor perceptions. Also ignored are other dimensions of the organization's solicitation strategy, such as the familiarity of the charity and the portrayal of the help recipient. It is important to integrate all of these effects, because helping behavior most likely is a function of all of these influences.

Two calls for such an integration come from studies by Burnett and Wood (1988) and Guy and Patton (1989), both of which make laudable efforts to generate greater attention to helping behavior from marketers. These authors review some of the theoretical underpinnings of helping behavior and propose models of the donation decision process. We extend these earlier works in three important directions. First, we explicitly account for the diverse motivations that underlie helping behavior to answer the question, Why do people help? Both Burnett and Wood and Guy and Patton suggest that this is a key issue and conclude that diverse motivations may differentially affect the person's helping decision process. However, the different motivational routes are not built into their proposed models. Second, we specifically address the role of the soliciting charitable organization in the helping decision process. Most work in helping behavior has focused on the help that is rendered directly from a donor to a needy beneficiary. In contrast, a charity acts as an intermediary between the donor and the ultimate beneficiary. As Burnett and Wood (p. 35) note, though there is a great deal of research on direct help by the donor to the beneficiary, "we know nothing about the relative impact of the agent representing the recipient." Third, in examining donor motivations and organizational context in tandem, we present testable propositions on promotional strategies for charities.

\section{A Conceptual Framework of Help Rendered to Charitable Organizations}

A conceptual framework delineating helping behavior and its antecedents, moderators, and consequences is shown in Figure 1. Several variables may affect the help rendered to a charity: Some can be controlled by the charity (e.g., its appeals for help), whereas others are beyond its direct control (e.g., the state of the economy). We present the controllable promotional variables as antecedents of helping behavior and the uncontrollable variables as moderators that affect the relationship between the antecedent variables and the helping behavior.

Antecedents. The charity may affect helping behavior through several antecedent variables under its control. For example, within its promotional program, the charity may control source variables (i.e., variables relating to the charity's image, such as whether it is perceived as efficient), message variables (e.g., whether it emphasizes the beneficiary's similarity to the potential donor), and request variables (e.g., whether the requested help involves money, time, blood).

Moderators. The impact of the promotional variables on helping behavior may be moderated by several uncontrollable factors. For ease of exposition, we have divided these into donor and nondonor variables. Some donor variables are persistent; that is, they persist across solicitations. These include perceptions (whether the cause is perceived as worthy), motives (whether the motivation is egoistic, such as gaining praise for helping, or altruistic, such as alleviating the need), and abilities (e.g., the donor's physical, financial, or psychological resources). Other variables are transient or specific to a solicitation. These include mood state (e.g., whether the donor is in a good mood when exposed to the appeal for help), media exposure (e.g., whether the donor watches the television program in which the solicitation is made), and attention (e.g., whether distractions in the environment prevent attending to the appeal). Whether help is rendered also may be affected by nondonor variables, such as government policies (e.g., tax deductions), the state of the economy (e.g., whether the economy is in a recession), social norms (e.g., greater giving at Christmas time, particularly to children's causes), technology (e.g., medical advances in transplanting body parts), and competing charities (e.g., appeals, perceived relative efficiency).

Behavior. In response to the solicitation, the potential donor may respond with different degrees of helping behavior. One response may be not to help at all. If the donor chooses to help, it may be either token help (e.g., making a modest contribution to get rid of a persistent solicitor) or serious help (e.g., a substantial contribution to address the need).

Consequences. The consequences of helping behavior are manifold. First, the obvious consequences for the beneficiaries are whether their need is relieved. Second, there are consequences for the charity: The help generated determines the charity's level of success and aids adaptation by providing feedback in planning future solicitations. Third, there are social, cultural, and economic consequences for the donor's community, even when the beneficiary is not part of it (e.g., a person in the United States contributes to famine relief in Africa). Helping may affect the community's attitudes regarding the roles of private charities versus public institutions in helping the needy. It also may affect the number and growth potential of competing charities in the community. Finally, there are consequences for the individual donor. The degree of help given may affect the donor's future perceptions (e.g., learning about the charity by helping may lead to a more positive perception), motives (e.g., a person who feels guilty about not helping in the past may 
help later to relieve the guilt), and abilities (e.g., the size of prior help may affect the ability to provide future help). Most significant for the charitable organization, prior helping behavior may affect future helping behavior.

Clearly, the task facing the charity is to adapt those variables under its control to the uncontrollable variables in the environment so as to generate the greatest helping. Discussing all these variables is beyond the scope of our article. We focus instead on how the charity may adapt its solicitation strategy to critical donor variables. Toward this end, we present a synthesis of insights into the donor decision process, drawing on work in marketing, economics, sociology, and social psychology. Next, we examine specific charity-controlled variables as interventions that affect the helping decision process and present propositions regarding promotional strategies to maximize the likelihood of help.

\section{The Donor's Decision Process: Propositions on Promotional Strategy}

We focus on generic helping rather than on specific forms of help, such as donating blood, versus money, versus time, and so on. The decision process must be adjusted for different kinds of helping, such as emergency versus nonemergency helping, planned versus spontaneous helping, or doing versus giving (Smithson, Amato, and Pearce 1983). There also are likely to be modifications based on the severity of the request. For example, the request to donate a body part evokes a more involved decision process than one to donate a dollar to charity (Simmons, Marine, and Simmons 1987). However, the basic steps in the decision processes are the same for different kinds of helping (Smithson, Amato, and Pearce 1983). It is the commonness of such "generic" helping that is our focus. The generic helping decision process involves four sequential steps: (1) perception of need, (2) motivation, (3) behavior, and (4) consequences (Batson 1987; Krebs and Miller 1985). In Figure 2, we present a map of the helping decision process and graphically summarize the propositions.

As is shown in Figure 2, the helping decision process is not linear-it may be truncated at many junctures, leading to noncompliance with the help request. Charities wishing to shepherd donors through the decision process therefore must be sensitive to these critical choice points. We subsequently discuss specific steps in the decision process and propositions regarding charities' promotional strategies.

\section{Step One: Perception}

The helping decision process typically begins with the potential donor's perception that the charity is in need of help. This perception may be triggered by personal experience (a harsh winter may remind a person of the need for warm clothing in a shelter for the homeless) or exposure to information. The information may come from personal sources such as family and friends or from nonpersonal sources. The nonpersonal sources may include appeals from the charity itself or media reports regarding the charity or the cause.
Perception of need may not result automatically when donors are exposed to the charity's appeal for help. It is generated only when the prospective donor perceives a significant gap between the beneficiary's current and ideal states of well-being or between what is and what should be (Batson 1987). The charity may influence this need perception through its image, its depiction of the cause of need, and its portrayal of the beneficiary.

For perception of need to result, prospective donors first must believe the charity's message depicting need. Whether they do so may be a function of the charity's image. Social psychological literature shows that messages are more likely to be accepted when the messengers are familiar and credible than when they are not (Kelman 1961). Consequently, donors may be more likely to accept the portrayal of need when it comes from familiar and credible charities. When the charity's image is lacking - when it is obscure or lacks credibility-prospective donors may either ignore the message or even distort it (e.g., "the message merely hypes up need to manipulate donors"). The image of the charity thus may be the single most critical element of its promotional program because it may determine whether the first step of the helping decision process-perception of need-is initiated.

Why should donors rely on charity image? Charities are intermediaries promising to act on behalf of donors, by reliably delivering the help to needy recipients. In agency theory terms, donors are principals who rely on charities to act as their agents in disbursing help (Stark 1989). A major concern for principals in such relationships is the problem of adverse selection, that is, the problem of choosing the right agent - the one with desirable characteristics such as efficiency or effectiveness. For donors, the charity's image may provide cues as to how well it will function as their agent. Consistent with this reasoning, studies show that messages from charities that are perceived as familiar or well known, efficient, and effective result in greater perceptions of need and greater helping behavior (Harvey 1990).

Familiarity is typically measured in terms of general awareness of the charity; it is a measure of whether the charity is high or low profile. Being high profile is not necessarily good: the charity may be high profile for the wrong reasons (e.g., being cited for mismanagement or fraud). Efficiency and effectiveness deal with how well the charity functions. Efficiency is the proportion of donations that goes to the ultimate beneficiaries, as opposed to administrative or fund-raising activities, for example. Effectiveness refers to the charity's perceived success in meeting its objectives.

Does the charity's image have the same influence in all solicitation contexts? Social impact theory (Latane 1981) suggests not; the influence of the charity's image may be a function of the media context in which the appeal is made. Social impact theory proposes that people pay more attention to immediate cues than to remote cues, because the former have greater social impact. How much donors rely on the charity's image may be determined by whether more immediate cues are available. For example, if a charity's appeal for help is presented in a door-to-door campaign, the number, sex, appearance, and so on of the solicitors are more immediate social cues than the charity's image and 
should have greater social impact. If the appeal is presented in the mass media, however, potential donors do not have other, more immediate cues on which to rely, and hence the charity's image may have more impact. The previous discussion leads to the following:

$\mathrm{P}_{1 \mathrm{a}}$ : The perception of need and, consequently, helping behavior depends on the charity's image. The greater the charity's perceived positive familiarity, efficiency, and effectiveness, the greater the need perception and helping behavior.

$\mathrm{P}_{1 \mathrm{~b}}$ : The impact of the charity's image varies by media context. It has a greater impact in mass media appeals than in personal solicitations (e.g., door-to-door, telephone).

Charities also may influence the perception of need through their explanations about the cause of need (Krebs and Miller 1985). Perception of need and, consequently, helping appears to be greater when the beneficiary's need is caused by external, uncontrollable factors than when it is caused by his or her own actions (Griffin et al. 1993). There is theoretical support for this finding in organizational jus- tice literature (Tyler 1994), which suggests that people are concerned about the fairness of allocated outcomes (distributive justice) and the procedures used to allocate the outcomes (procedural justice) (Bies 1987; Greenberg 1987). People asked to allocate resources are concerned about the fairness or equity of the allocation: Outcomes should be consistent with inputs (Tyler 1994). When beneficiaries appear to have caused their own need, the outcomes (their need) may appear consistent with their inputs; hence, potential donors may not perceive any need. However, when people appear to be needy through no fault of their own, the outcome may be perceived as inequitable and donors may seek to restore justice by acknowledging the need and helping to reduce it. For example, in response to the 100 "neediest" cases advertised in the New York Times, more donations were given to people whose need appeared to be not of their own doing (e.g., abused children) than to people who seemed to have "caused" their own need (e.g., recovering alcoholics) (Berkowitz 1972).

\section{FIGURE 1}

\section{A Conceptual Framework of People's Helping Behavior Toward Charities}

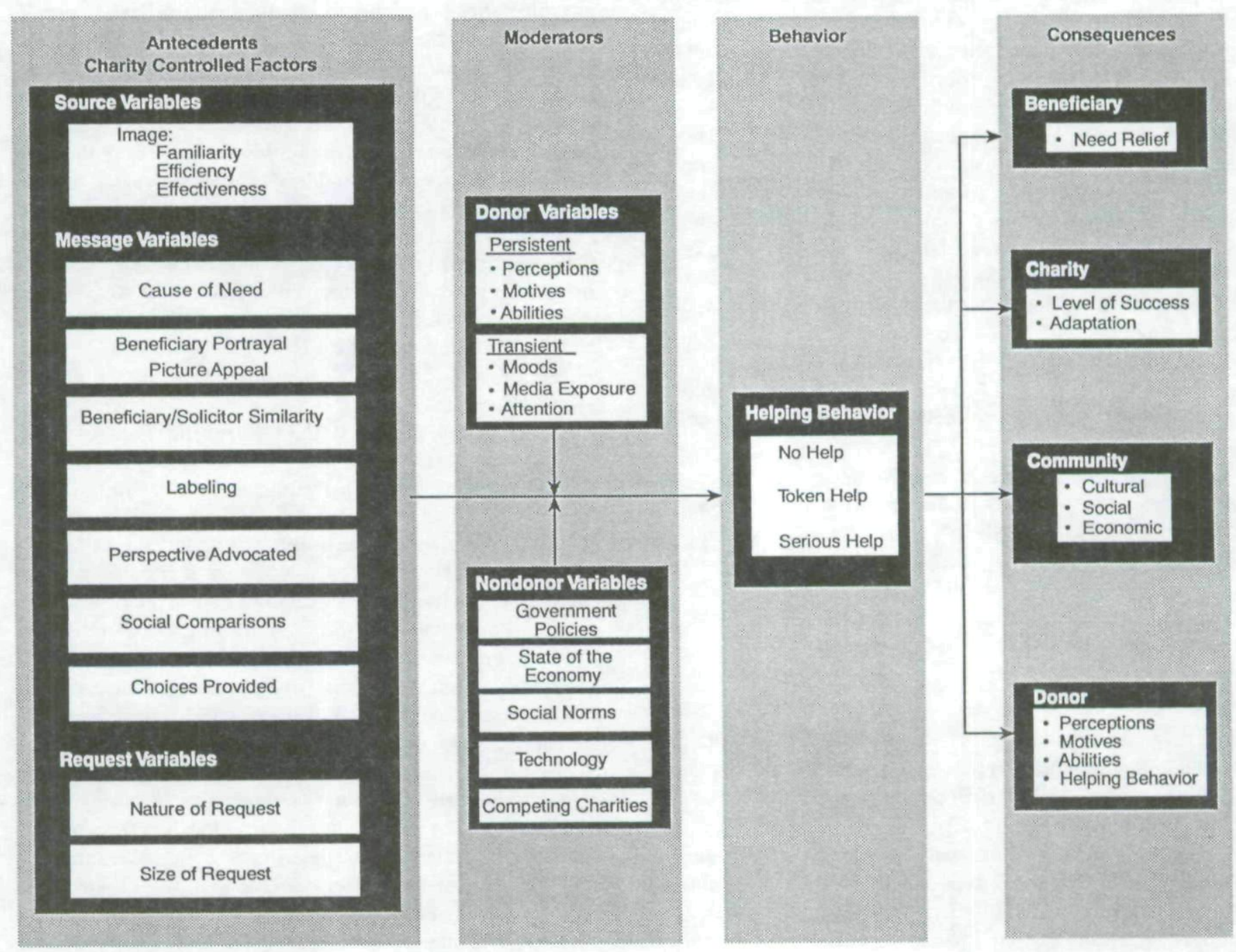


FIGURE 2

A Process Map of People's Helping Decisions

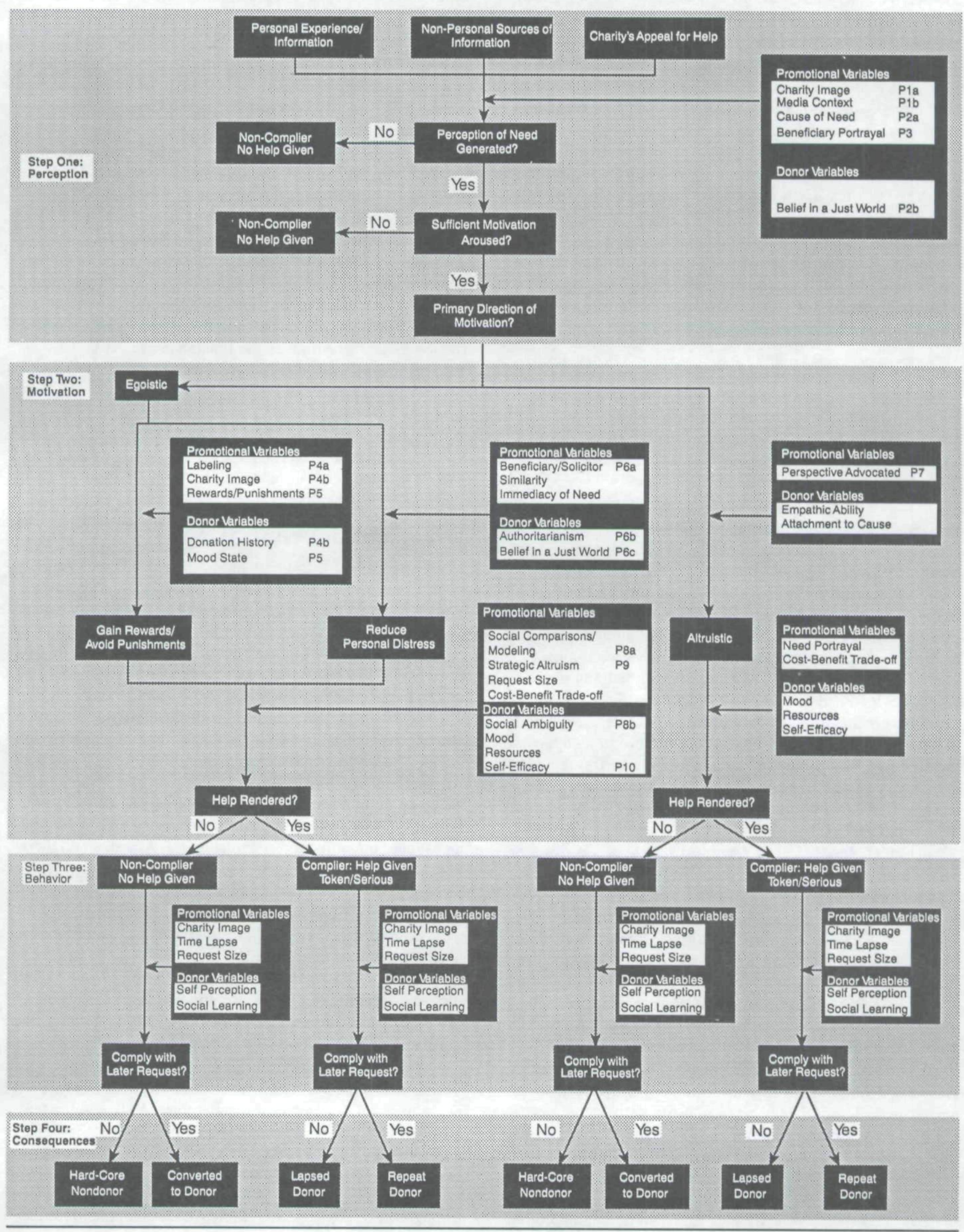


The effect of the cause of need may be moderated by one manifestation of the distributive justice motive, a personal characteristic termed belief in a just world (Lerner 1980), which is the belief that this is a just world in which people get what they deserve in life. To a person who holds this belief, the suffering of an "innocent victim" (e.g., a person who contracted AIDS through a blood transfusion) seems undeserved - the gap between the current and ideal states is high-and the need seems extremely salient. On the other hand, when confronted with people whose suffering seems to be self-induced, this person does not perceive a gap between the current and ideal states ("After all, they merely got what they deserved"). Thus, a person with a high belief in a just world may be more inclined to donate to breast cancer research (a disease perceived to be outside the victim's control) than to lung cancer research (a disease-rightly or wrongly - perceived to be a result of the victim's choice to smoke).

$\mathrm{P}_{2 \mathrm{a}}$ : The perception of need and, consequently, helping behavior is affected by the perceived cause of need. Need perception and helping are greater when the need is perceived to be due to external causes outside the beneficiary's control than to internal causes under the beneficiary's control.

$\mathrm{P}_{2 \mathrm{~b}}$ : The greater the potential donor's belief in a just world, the stronger the association between the perceived cause of need and helping.

As we discussed previously, prospective donors perceive need when they believe that a gap exists between the beneficiary's current and ideal states. Charities typically attempt to increase the salience of the gap through their beneficiary portrayal. This issue is fraught with difficult choices. The beneficiary portrayal must be strong enough to command attention but not so strong that it is viewed as manipulative. If appeals are viewed as a hard sell, helping may actually be lessened (Moore, Bearden, and Teel 1985). In treading this fine line, a critical issue for a charity is whether to emphasize the need by including a picture in its appeals. Furthermore, if a picture is used, should it portray a needy beneficiary or a helped beneficiary? The answers are unclear because there are only two studies of the use of pictures, and their results are contradictory.

Isen and Noonberg (1979) report that in a door-to-door solicitation, the use of a needy beneficiary picture appeal (a starving child) in conjunction with a verbal appeal resulted in lower helping than the use of the verbal appeal alone. Thornton, Kirshner, and Jacobs (1991) report that under identical conditions, there was no significant difference between the two conditions. To explain these contradictions, Thornton, Kirshner, and Jacobs speculate that the picture appeal had no effect because the solicitors might have had so much social impact that donors ignored the picture; however, this does not account for the reduced helping reported by Isen and Noonberg. Isen and Noonberg propose that the needy picture appeal may have reduced helping because it (1) created a bad mood in donors, (2) made the task cognitively complex, or (3) created reactance in potential donors. The mood explanation is not tenable, because a bad mood does not always reduce helping; at times, it increases helping (for a review, see Clark and Isen 1982). The cognitive complexity explanation is unconvincing because pictures actually make messages easier to process (e.g., Childers and Houston 1984). Reactance formation, however, remains a plausible explanation for the observed results.

Reactance theory (Brehm 1966) posits that people possess certain behavioral and attitudinal freedoms. When these freedoms are threatened by persuasive appeals, reactance is aroused. The charity's appeal, for example, may threaten the donor's freedom to spend money or time in another fashion. When the charity uses too strong an appeal for help (e.g., combining a verbal appeal with a needy picture), it may be seen as manipulative or threatening to the potential donor's freedom to not help. This may cause strong reactance: The donor may react by minimizing the perceived need and not complying with the help request. If, however, a verbal appeal is combined with a picture of a helped beneficiary (e.g., a woman safe in a battered woman's shelter), it may be less threatening to the donor's freedom not to help. That is, the helped picture may reduce the reactance caused by the verbal appeal and, thus, increase the level helping.

$\mathrm{P}_{3}$ : Perception of need and, consequently, helping is affected by beneficiary portrayal. Compared to a verbal appeal only, adding a needy beneficiary picture should result in lower perceived need and helping, whereas adding a helped beneficiary picture should result in greater perceived need and helping.

\section{Step Two: Motivation}

The motivation for helping may be egoistic, altruistic, or both. Egoistic motivation has the ultimate goal of increasing a person's own welfare (Martin 1994). It has been further distinguished into two categories based on the focus of a person's concern for him- or herself (Batson 1987). The first category is the motivation to gain rewards for helping or avoid punishment for not helping (Cialdini et al. 1987). These rewards and punishments include intangible cognitive and psychological outcomes, as well as tangible benefits and penalties; they also may be conferred by self (e.g., pride versus guilt) or by society (e.g., praise versus censure). This category comprises such motivations as securing recognition, a sense of belonging, career advancement, tax advantages, peer pressure, and political gains (American Association of Fund-Raising Counsel 1994).

The second category deals with a different egoistic response - that of concern for a person's own distress (Piliavin et al. 1981). When confronted with someone who is needy, a person may experience distress. The person then may try to reduce personal distress by helping or escaping the need situation (e.g., ignoring the message). The motivation is egoistic because even when it results in helping, the ultimate goal is to reduce the donor's personal distress.

Altruistic motivation, in contrast, has the ultimate goal of enhancing the welfare of the needy (Martin 1994), even at the expense of a person's own welfare. Although the term altruism is fairly new (coined by Comte 1851), the debate over whether true altruism exists - that is, whether behavior can be motivated by other than obvious or subtle self-interest-has held an abiding fascination for philosophers and scholars of every age. Within Western thought, the Greek 
philosophers (notably in Aristotle's Ethics and Plato's Lysis) are credited with advancing egoism as the central tenet of human behavior. The alternative perspective, that at least some behavior is truly altruistic, is traced to the JudeoChristian religious tradition and its emphasis on "loving thy neighbor as thy self" (for a detailed examination of the philosophical debate and its development, see Batson 1991).

Today, there is a consensus that at least in some situations, true altruism exists. The existence of altruistic motives, as well as the distinction between the two categories of egoistic motives, is well supported by empirical studies (Batson et al. 1988; Fultz, Schuller, and Cialdini 1988; Griffin et al. 1993). The logic behind the studies is simple. When people help for egoistic reasons, helping is just a means to an end, namely, attaining rewards, avoiding punishments, or escaping personal distress. Thus, when they are provided with alternative ways to reach their goals-for example, by allowing them to escape the situation and hence the needthey will readily abandon the needy target. On the other hand, if they are altruistically motivated, they will ignore the alternatives and persist in helping until the need is met (Davis 1994). This pattern holds and provides evidence for the distinct motivational paths (for reviews, see Batson 1987, 1991; Dovidio, Allen, and Schroeder 1990).

It is possible for people to simultaneously experience several motives, some of which may even be conflicting. The opportunity to help by volunteering at a disaster site may evoke an altruistic motive to help others as well as an egoistic motive to avoid the distress caused by human anguish. If the different motivational states are compatible, there is an additive effect. If they are not, there is a drive to satisfy the stronger motivational state (Batson 1987). We next explore the specific motivations.

Egoistic motivation to gain reward and/or avoid punishments. The potential donor faced with a helping situation may form expectations regarding the rewards (or punishments) for helping (or not helping). The expectations may stem from the donor's learning history (direct and vicarious experiences), or they may be created by the organization's appeals for help. For example, a charity soliciting blood donations may invoke the rewards of helping (e.g., promising first-time donors $\$ 25$ ) or the punishments for not helping (e.g., suggesting that nondonors are sure to experience pangs of guilt).

Alternatively, the charitable organization could use labeling to affect donor expectations. Labeling involves giving people labels (purportedly based on their behavior) to motivate them to behave in a label-consistent fashion. Labeling is presumed to lead the person being labeled to believe he or she possesses the characteristics of the label (Kraut 1973). Thus, the label may activate expectations regarding the rewards for label-consistent behavior and the punishments for inconsistent behavior. For example, labeling people as kind, generous, or helpful elicits greater motivation to help and greater helping (Swinyard and Ray 1977) and fosters favorable attitudes toward the soliciting organization (Moore, Bearden, and Teel 1985).

Labeling is only effective when the person being labeled accepts the label (Allen 1982). As we previously discussed, messages are more likely to be accepted when they come from credible sources. Because familiar sources have more credibility, it may appear that labeling would always be more effective for a high-profile charity than for its low-profile counterpart. However, self-perception theory (Bem 1972) suggests this may not be the case. The impact of the charity's profile or familiarity may be moderated by the donor's donation history.

People contacted for the first time may be more accepting of labels from high-profile charities than of those from low-profile charities because they view the former as more credible. Prior donors, however, may be more accepting of labels from low-profile charities, because people who have donated to low-profile charities are more likely to make internal attributions for their behavior (e.g., I must truly be generous to support a lesser-known charity). In contrast, people who have donated to high-profile charities may ascribe their behavior to the charity's familiarity (e.g., everyone gives to the Red Cross) rather than to themselves (e.g., I gave to the Red Cross because I am generous or helpful). In self-perception terms, the presence of external factors (the high-profile of the organization) may lead to the discounting of internal motivations (Scott 1978). In contrast, when the low-profile organization uses labeling with previous donors, the label should be consistent with their self-schema and therefore more effective (Tybout and Yalch 1980).

$\mathrm{P}_{4 \mathrm{a}}$ : Stronger motivation to help and greater helping result when potential donors are given labels congruent with helping behavior (e.g., kind, generous) than when such labels are not given.

$\mathrm{P}_{4 \mathrm{~b}}$ : The effectiveness of a labeling strategy depends on the person's donation history. When contacting people for the first time, giving labels congruent with helping behavior is more effective for charities that are familiar or wellknown than for those that are less familiar or less wellknown. When contacting people who have donated previously, the opposite pattern holds.

We have suggested that egoistic motivation may be aroused by the prospect of either gaining rewards for helping or avoiding punishments for not helping. Which of these is a stronger motivator may depend on the potential donor's mood state. People in a good mood are more responsive to gaining rewards than to avoiding punishments; those in a bad mood respond better to avoiding punishments than to gaining rewards (Cunningham, Steinberg, and Greu 1980). Charitable organizations have little control over the potential donor's mood state (the mood being both transient and affected by any number of factors beyond the charity's influence). However, they can take steps to align their message to the possible mood state of donors. First, because of the demonstrated positive effects of good mood on helping behavior (Isen 1984), organizations can try to place their appeals in media contexts designed to create a good mood in their target audience (e.g., positive, upbeat forums such as Comic Relief, a popular television comedy program designed to raise funds for the homeless). Second, when presenting their appeals in such media contexts, organizations may do well to avoid punishment-oriented messages (e.g., "Think of how guilty you will feel for not helping") and in- 
stead emphasize the rewards of helping. The previous discussion suggests the following:

$\mathrm{P}_{5}$ : When contacting potential donors who are in a good mood, emphasizing the rewards for helping is more effective than emphasizing the punishments for not helping. The opposite is true when contacting potential donors who are in a bad mood.

Egoistic motivation to reduce personal distress. In some potential donors, the perception of need may cause personal distress. This in turn leads to helping, ${ }^{2}$ especially when the donors perceive the beneficiary as being similar to them (Piliavin et al. 1981). Why should similarity matter to donors? One explanation proffered by economists evokes the evolutionary significance of physical similarity (Samuelson 1993; Simon 1993). Economists have traditionally viewed helping behavior as a paradox: Rational, utilitymaximizing people engage in behavior that appears not to enhance their personal well-being (i.e., behavior whose costs appear to outweigh the benefits). This stream of research suggests that apparent altruism at the individual level might actually be egoism from the vantage of evolution. Specifically, helping behavior may enhance the person's, genotype's, or group's prospects for survival. Helping similar others, it is argued, may be a "selfish" way of ensuring that a person's own genetic pool is preserved, because a similar beneficiary is more likely to belong to the helper's "ingroup" (group selection) or to be kin (kin selection) (Margolis 1982). Personal distress when seeing the need of a similar beneficiary may thus have evolutionary significance.

The strategy of emphasizing beneficiary similarity would be too restrictive if only physical similarity counts. However, psychological studies suggest that perceived beneficiary similarity on other, nonphysical dimensions also creates personal distress. For instance, similarity of values or attitudes may be just as powerful as physical similarity (Heider 1958). Thus, a charity may rely on shared values and attitudes to create a common bond between the helper and the beneficiary. For example, adults may give more readily to Toys for Tots than to the American Cancer Society at Christmas time if they perceive Toys for Tots as embodying a shared value that the holiday season should be especially joyful for children. In addition to beneficiary similarity, charities may also capitalize on solicitor similarity, by matching solicitors to similar potential donors (e.g., by ethnicity, language preference). Support for the positive effects of such matching comes from the literature on sales force effectiveness.

$\mathrm{P}_{6 \mathrm{a}}$ : Greater personal distress and stronger motivation to help result when appeals stress the similarity of the beneficiary or solicitor to the potential donor than when they do not.

The effect of the beneficiary's or solicitor's similarity on the personal distress of the donor may be moderated by his

${ }^{2}$ Charities must be careful not to induce too much distress. If personal distress is excessive, donors may seek to escape the need situation physically (e.g., changing the television channel when an appeal involves graphic images of starvation) or psychologically (e.g., minimizing the need by rationalizing that it is exaggerated to win sympathy). or her authoritarianism and belief in a just world. Compared to people with egalitarian personalities, people with authoritarian personalities have a lower tolerance for "out-groups" and opinions that conflict with theirs; therefore, seeing the need of people who are dissimilar may not be disturbing. Authoritarian people also are more likely to find people who are similar more appealing. For instance, the similarity of the beneficiary has been shown to lead to greater personal distress and therefore to more helping among potential donors with authoritarian personalities than among those with egalitarian personalities (Mitchell and Byrne 1973). Beneficiary or solicitor similarity also may be more important to people with a strong belief in a just world than to those with a weak belief in a just world. People with a strong belief in a just world believe that people get what they deserve. Hence, the need of similar beneficiaries may cause them greater personal distress, because they might expect that they too might suffer similar consequences (if similar "inputs" should lead to similar "outcomes" in a just world). Consequently, we propose,

$\mathrm{P}_{6 \mathrm{~b}}$ : Beneficiary or solicitor similarity causes greater personal distress among potential donors with authoritarian personalities than among those with egalitarian personalities.

$\mathrm{P}_{6 c}:$ Beneficiary or solicitor similarity causes greater personal distress among potential donors with a strong belief in a just world than among those with a weak belief in a just world.

Altruistic motivation. In contrast to the egoistic motives discussed earlier, donors may also experience altruistic motives, especially if they experience empathy (Davis 1994). Empathy may be defined as being aware of another person's internal states and putting oneself in the place of another to experience his or her feelings (Hoffman 1984). Not everyone experiences empathy when confronted with someone who is needy. Research suggests that a person is more likely to experience empathy when he or she has high empathic ability ("the tendency to spontaneously adopt the psychological point of view of others," Davis 1983, pp. 113-14), prior experience with the need (a recovering alcoholic may more easily empathize with another person in the same state), or emotional attachment to the cause (Hoffman 1984).

Typically, a charity has little control over these factors other than to attempt to target people with these characteristics. ${ }^{3}$ However, the charity may affect empathy through the perspective advocated in its appeals. In an effort to encourage empathy, most charitable organizations currently encourage their potential donors to imagine how they would feel if they were in the beneficiary's situation. Unfortunately, this causes potential donors to focus on their own imagined distress and thus leads to a more negative affect (Aderman, Brehm, and Katz 1974), which would depress helping behavior. Charitable organizations might find it more prof-

\footnotetext{
${ }^{3}$ Some evidence suggests that charities might affect the emotional attachment of potential donors by using strong emotional advertisements (Bagozzi and Moore 1994). Although this is promising, more research is needed regarding the effectiveness of this strategy. Appeals that are too strong may lead to negative emotional responses of distress, fear, and denial, thus reducing empathy and consequently helping (Stayman and Aaker 1988).
} 
itable to instruct potential donors to imagine how the beneficiary would feel in the given situation. This has been shown to lead to a more positive effect (Davis et al. 1987), which should enhance the help rendered. The previous discussion suggests the following:

$\mathrm{P}_{7}$ : Greater empathy, and hence greater altruistic motivation, is created when the appeal for help asks donors to imagine how the beneficiary must be feeling than when the appeal asks donors to imagine how they would feel if they were in the beneficiary's place.

\section{Step Three: Behavior}

Following the motivation to help, the potential donor engages in the chosen behavior by complying or not complying with the request for help. If the donor complies with the help request, the help may range from token helping (making a nominal contribution) to serious helping (making a substantial contribution). The degree of help (none, token, serious) depends on a cost-benefit analysis. The benefits of a course of action may include attaining self- or social rewards, avoiding self- or social punishments, avoiding personal distress, or enhancing the other's welfare. These benefits may accrue from the end result (feeling good about volunteering for a good cause) as well as from the instrumental behavior (volunteering may be a good opportunity for social interaction). The costs involved may be financial (dollars contributed), physical (effort involved in volunteering), psychological (trauma associated with working with a terminally ill person), or social (significant others may disapprove of the cause). Costs also involve the opportunity costs of unchosen alternatives (dollars or time contributed to charities are resources that cannot be spent on other activities). Again, as with benefits, costs may accrue from the end result (personal time set back by total hours volunteered) and instrumental behaviors (having to work in undesirable surroundings such as in an inner-city neighborhood).

Commitment to behavioral alternatives: Egoistic motivation. Research suggests that whether the potential donor commits to helping or not helping depends on the perceived cost-benefit trade-off. The charity may affect this trade-off through the use of social comparisons (conveying that others have helped) and strategic altruism (conveying that helping is good strategy).

Sociological literature suggests that helping behavior may be enhanced by stressing that it is the norm (Gouldner 1960) through the use of social comparisons. Because normative behavior is reinforced by society, knowledge that others are behaving in a specific fashion should create pressure on a person to do so also. Specifically, people may reason, "If everyone is doing it, it must be a sensible thing to do" (Cialdini, Reno, and Kallgren 1990). Reingen (1982) demonstrates that providing a fictitious list of donors and donations resulted in higher compliance rates and higher average donations: The longer the list, the greater the donations. Having a neighbor solicit blood donations (activating normative behavior) was also shown to increase compliance (Independent Sector 1994; LaTour and Manrai 1989). Similar findings are reported for reducing littering in public places (Cialdini, Reno, and Kullgren 1990). Consequently,
$\mathrm{P}_{8 \mathrm{a}}$ : Greater helping behavior results when normative or social comparison appeals are used than when such appeals are not used.

Through social comparisons, charities may be providing donors with potential models for them to emulate. Studies show that people help more when they are exposed to role models who help (Wilson and Petruska 1984), presumably because the model provides information about the social norms for and the consequences of helping (Krebs and Miller 1985). Providing models through normative or social comparison appeals may be particularly effective in situations that are fraught with social confusion or ambiguity (Festinger 1954; Schachter 1959). When the behavior is widely established and well understood or when its costs and benefits are clear, there is no social ambiguity - a person need not rely on others for information on the appropriate conduct. When the behavior is rare or its consequences are not well understood, the situation is socially ambiguous, and people look for social cues to guide their behavior. Thus, social comparison appeals may be more effective in increasing behavior that is scarce (e.g., bone marrow donations among blacks and minorities) or about which misperceptions exist (e.g., that a person can contract AIDS by donating blood) than in increasing behaviors that are well established or whose consequences are well understood (e.g., being a bell-ringer for the Salvation Army). Hence, we propose,

$\mathrm{P}_{8 \mathrm{~b}}$ : The effectiveness of normative or social comparison appeals depend on the social ambiguity of the requested helping behavior. The appeals are more effective in increasing help when the behavior is not common in the donor's community or when there are misperceptions about it than when the behavior is common and the consequences are well understood.

As we previously discussed, charities may suggest that cost-benefit trade-offs must favor helping because significant others are engaging in helping behavior. Alternatively, they could suggest that helping is a sound strategy, thereby invoking strategic altruism. The economic literature on strategic altruism addresses the Samaritan's dilemma: how to help without perpetuating dependence and selfish behavior in the recipient (Becker 1981; Bruce and Waldman 1990, 1991). Using the metaphor of the parent-child relationship, it examines when and how a parent should help a potentially rotten child. ${ }^{4}$ Knowing that the parent will come to his or her aid, the rotten child may have no incentive to behave responsibly. In response, potential helpers focus on carefully choosing whom, when, and how they help and monitor the impact of the help on the recipients.

Strategic altruism suggests that choice enables donors to optimize their resource allocation and should lead to greater helping (Bruce and Waldman 1991). Thus, charities can enhance helping by giving potential donors greater choice in specifying the beneficiaries, type, and timing of help. This

\footnotetext{
${ }^{4}$ The metaphor extends to transfers of wealth in other relationships, such as from a government (through welfare programs) or private citizens (e.g., through charitable contributions) to needy recipients.
} 
beneficial effect of choice is validated by two other sources. Studies of blood donation patterns show that providing choice in a relatively trivial matter such as what arm from which to draw blood leads to greater perceived benefits and lower perceived costs to the donor (Mills and Krantz 1979). Research on the effects of perceived choice in other, nonhelping contexts also suggests that choice leads to positive psychological and behavioral outcomes (Hui and Bateson 1991).

Charities can improve perceived choice by providing greater options to donors. For example, some charities allow donors to specify the age, sex, and geographic region of the intended beneficiary (e.g., Children's Christian Fund allows donors to sponsor a child with a specific profile). This practice runs the risk of leaving less appealing beneficiaries underfunded. Charities in this situation may still provide choice in the timing of donations (e.g., lump sum versus quarterly) as well as in the type of donations (e.g., time, money). Consequently, we propose,

$\mathrm{P}_{9}$ : Greater helping results when charities allow donors to practice strategic altruism by providing donors with choices regarding whom, when, and how they help than when such choices are not provided.

To help, donors must believe in their self-efficacy, which is the conviction that a person can successfully execute a behavior to produce a desired outcome (Bandura 1983). Selfefficacy has been linked to people's willingness to undertake a wide range of behaviors (Shelton 1990). People who lack self-efficacy regarding a behavior doubt that they can perform it, view it with anxiety, imagine negative consequences, and avoid the behavior. How do people develop notions of self-efficacy? It may stem from direct or vicarious experiences (performing the behavior or watching others perform it) or from persuasion (exposure to information that a person can or cannot perform a behavior) (Maddux and Stanley 1986).

Charities may thus enhance donors' self-efficacy through their appeals for help. This may be done in the presentation of the size of need and requested help or by emphasizing that significant (i.e., highly esteemed) others are helping. When the need appears enormous, donors may believe that they are powerless to reduce it; this lack of selfefficacy may lead to their choosing not to help at all. To counter this trend, the charity may focus on a manageable segment of the need (e.g., helping one needy child as opposed to the starving millions), assuring donors it possesses the ability to provide serious help. Or, donors may believe that effective help requires contributions beyond their means. In this case, the charity may adjust the size of the requested help to emphasize that even a small donation is effective and appreciated. Alternatively, they may emphasize that significant others are helping. As we discussed previously, social comparisons can provide information on appropriate behavior. Such models of helping may also help donors develop vicarious expectancies of self-efficacy (e.g., If my neighbor can help, I can, too). Consequently, we propose,
$\mathrm{P}_{10}$ : Greater helping behavior results when charities persuade donors of their self-efficacy in helping than when they do not.

Commitment to behavioral alternatives: Altruistic motivation. The process by which the potential donor commits to behavioral alternatives under altruistic motivation is largely the same as in egoistic motivation. (We subsequently note a few differences.) For an altruistically motivated person, the magnitude of altruistic emotion (and the benefit of satisfying it) is proportional to the magnitude of the perceived need. Therefore, we expect that appeals emphasizing the need of the recipient should generate the most helping from these donors. Altruistically motivated donors also are presumably more focused on the need of the other, and hence they might be less sensitive to other factors (e.g., their own resources, their mood states, social comparisons) in evaluating alternatives than are their egoistically motivated counterparts (Batson et al. 1988).

It also appears that people motivated by altruistic concerns are more likely to provide serious help than token help (Clary and Orenstein 1991). Studies have demonstrated that egoistically motivated people view help as a means to an end. When given alternative ways to reach that end (e.g., gaining recognition for merely trying to help as opposed to helping effectively), egoistically motivated people, trying to gain the most benefits for the least costs, may choose token helping (Davis 1994). In contrast, altruistically motivated people are driven by the other's need. Consequently, they may either help or not help, depending on the cost-benefit trade-offs. They should be less likely to engage in self-serving token helping behavior because they recognize its futility in alleviating need (Batson 1987).

\section{Step 4: Consequences}

As is depicted in Figure 1, the consequences of helping behavior are far-reaching, affecting the beneficiary, charity, donor, and community. We focus on the consequences of helping behavior and the likelihood of subsequent help. Repeated help has not received adequate attention, primarily because few longitudinal studies have been conducted on this segment (Piliavin and Callero 1990); indeed, this area of research has been termed speculative (Burnett and Wood 1988). Thus, we do not offer propositions for this section but instead briefly discuss promising research streams.

Compliers. People who have helped in the past, or compliers, may continue to help, thereby becoming repeat donors, or they may refuse to help again, thereby becoming lapsed donors. A critical issue for charities in creating repeat donors is how much to ask for in the next help request. One strategy is to make escalating requests, that is, follow a small request that is honored with a later, larger request for help: This approach is termed foot-in-the-door (Freedman and Fraser 1966). Foot-in-the-door is presumed to work, because people who have complied with a small, initial request are expected to attribute their initial compliance to a distinctive favorable disposition to the cause or charity (I must have helped because I truly believe in the cause). When such attribution occurs, people feel pressured to continue to help 
in order to appear consistent. If people are able to find other, external reasons for their compliance, the act loses its distinctiveness and there is no pressure to continue helping (Zuckerman, Lazzano, and Waldgeir 1979).

Hence, foot-in-the-door may not be equally effective for all charities. When people help a high-profile charity, compliance may lose its distinctiveness, with donors reasoning, for example, that anybody would help the Salvation Armyit is such a well-known organization. On the other hand, when people help a low-profile charity, they are more likely to view the initial help as distinctive and hence feel pressured to continue to help. ${ }^{5}$ The strategy of escalating requests thus may be more effective for low-profile charities.

Recovering lapsed donors poses formidable challenges (Squires 1992). Having once helped, why do some donors lapse? Charities may find the insights from behavior modification particularly applicable here (Luthans and Kreitner 1985); namely, people's behavior is strengthened, maintained, weakened, or modified by its consequences. That is, people persist in behavior that is rewarded or has positive consequences and desist from behavior that is punished or has negative consequences. When donors lapse, perhaps helping is no longer rewarding to them, and the charity may do well to probe why. It is possible that the donor believes the help situation no longer meets his or her needs. For example, a student who volunteers in order to gain a resume item may have no incentive to continue once that goal is met. The charity may then focus on a different set of needs that helping can satisfy. Such follow-up is costly, and organizations may wish to tailor the level of recovery effort to the likelihood of recovery and the payoffs of recovery, using such factors as number of years lapsed and the status at the time of lapse (e.g., level of giving, annual versus multiple gifts per year) (Kuhn 1989).

Noncompliers. People who have denied an initial request for help, or noncompliers, may continue to refuse to help, thereby becoming hard-core nondonors, or they may accede to a later request for help, thereby becoming converted to donors. In attempting to convert nondonors to donors, charities may find guidance in the research on the door-in-the-face technique (Cialdini et al. 1975), which focuses on the effect of noncompliance on later requests for help. In this procedure, a subject is asked to comply with a large, initial request for help. Following the subject's refusal, a smaller, critical request for help is made. It is proposed that the person who turns down the larger request for help views the second, smaller request as a concession on the part of the solicitor. Norms of reciprocity (Gouldner 1960) are then expected to prevail, with the subject reasoning that a similar reciprocal concession is in order and then acceding to the smaller request for help. The success of the technique depends on the person's perceiving a concession on the part of the solicitor and feeling obligated to reciprocate. Again, the perception of the charity may dictate whether this is an effective strategy. For the potential donor

\footnotetext{
${ }^{5}$ The attributions people make are only one reason for their helping low-profile charities. Another may be that they believe their help will make a greater difference in these obscure charities than in high-profile ones.
}

to feel obliged to reciprocate, it is important that he or she view the soliciting charity as powerful or high-profile, because a concession is only viewed as magnanimous if made by a powerful bargainer; in a weak counterpart, it is viewed as a retreat. Hence, the donor may experience a greater obligation to reciprocate a concession by a high-profile charity (the Red Cross) than a low-profile one (Inter Faith Hunger Appeal).

An important issue in tracking donors is whether they have switched from one form of helping to another (a donor who volunteers time may be in a time crunch and choose to donate money instead) or from one cause to another. Some evidence suggests that helpers are consistent: They may move from one activity to another but they continue the general pattern of helping (American Association of Fund-Raising Counsel 1994). If this is true, identifying helping-prone customers may be an effective strategy for charitable organizations (Danko and Stanley 1986).

\section{Discussion}

Trends indicate that the already significant demand for charities' services will increase in the years to come (Independent Sector 1994). To meet these growing needs, charities may need to devise effective promotional strategies to elicit greater help from donors. Literatures in which helping has been studied (e.g., economics, sociology, social psychology) are too fragmented by disciplinary boundaries to be of much value in this task (Schlegelmilch, Diamantopouos, and Love 1992). Consequently, we attempt to advance theoretical understanding of such underresearched issues as what factors affect helping behavior, why people help charitable causes, and what promotional strategies are most likely to enhance helping.

To understand the factors that affect helping, we present a conceptual framework of helping behavior, including its antecedents, moderators, and consequences, in Figure 1. This framework is useful in synthesizing insights from different disciplines. Consider the focus of two fields of study: Marketing research in the area has focused primarily on narrow aspects of the charity's solicitation, such as the size of the request for help. In contrast, social psychological literature has emphasized donor characteristics - especially different motivations - and their effects on helping behavior; because of the focus on a person directly helping a needy recipient, the influence of an intermediary charity is not investigated. By integrating the insights from these (and other) disciplines, the framework enables theorizing to move beyond the prediction of main effects (either charity or donor variables) to the richer investigation of the interaction effects of the charity and donor variables on helping behavior. However, significant gaps remain in our understanding of other aspects of the framework. For example, little is known about the role of macroenvironmental variables (nondonor moderators such as the state of the economy and government policy) in shaping helping behavior. The consequences of helping behavior are also virtually unexplored and must be examined in longitudinal studies.

To understand why people help charities, we examine the donor's decision process (see Figure 2) and how chari- 
ties' promotional strategies can positively influence it to enhance helping, and we develop propositions regarding the impact of these promotional strategies. Consider, for instance, the initial step of perception of need. The propositions suggest that the image of the charity, cause of the need, and the portrayal of the beneficiary may determine whether donors even perceive that the need exists. This conceptualization has significant practical and theoretical implications. From a practical standpoint, raising donations for causes such as drug rehabilitation or treatment of sexually transmitted diseases may pose a formidable challenge if people believe the situation is caused by or is under the volition of its victims. Stressing that the causes are at least partially outside the victims' control should help enhance perception of need and helping behavior. These theoretical insights into beneficiary portrayal must be extended to charities that deal with multiple beneficiaries.

We have focused on how charities portray a single beneficiary or a segment of beneficiaries. Some organizations follow this approach, clearly aligning themselves with a specific segment (e.g., Save the Children foundation). Other organizations benefit a variety of recipients and causes (e.g., the United Way). Clearly, these multiple constituencies vary in the extent to which they are perceived as "causing" their own need. It is possible that in such instances, donors are helping the charitable organization and not a specific beneficiary. Further research must empirically verify the implications of beneficiary portrayal for an organization that has multiple beneficiaries.

Heeding earlier calls for attention to the diverse motivations that may underlie helping behavior, we examine the different motivational paths to helping and the factors that guide the helping decision on each path. The presence of distinct motivational paths has received considerable research support in the social psychological, sociological, and economic literature. Marketing, however, has hitherto relied only on anecdotal evidence regarding the different motivations behind donations to charitable organizations (Sharpe 1987). By formalizing the motivational routes - to gain rewards or avoid punishments, to reduce personal distress, to alleviate the other's need-we enrich current understanding of the helping decision process. This understanding also can help charities recruit and sustain donors by aiding in pairing potential donors with appropriate helping opportunities. Charitable organizations (e.g., Big Brothers/Big Sisters of America, hospitals) routinely screen volunteers before accepting their help. If a volunteer is identified as motivated by social rewards (e.g., praise, recognition), the organization may be better off placing the volunteer in a high-visibility position (e.g., as a receptionist) than in a low-visibility position (Omoto and Snyder 1989).

The process map also reflects our conceptualization of different degrees of helping behavior (no help, token help, serious help), instead of a dichotomy of helping or not help- ing. Current research enables us to offer propositions regarding the conditions under which helping behavior (either token or serious help versus no help) is more likely. However, there remains a significant gap in the understanding of the conditions under which token versus serious help is rendered. For example, we have posited that social comparisons result in a greater likelihood of helping. Would people responding to such appeals (e.g., everyone is helping) try to make token contributions so that they can reap the benefits of helping at minimal cost?

Another area that must be addressed is the consequences of helping. Because of the lack of adequate research in this area, we have not offered propositions regarding the effects of initial helping behavior; however, we have identified several potentially useful research streams to guide theorizing in this area. Current marketing literature ignores the differences between charitable organizations (e.g., a familiar, well-known versus a less familiar, less well-known organization), recommending universal strategies for all organizations. We advocate recognizing these differences and adapting the solicitation strategies accordingly. Consider, for example, the choice between foot-in-the-door and door-in-theface solicitation techniques. Our discussion suggests that foot-in-the-door may be more effective for less familiar organizations, whereas door-in-the-face may be better for more familiar organizations.

Most of the propositions presented require a knowledge of the donors' persistent and momentary characteristics; however, there is no syndicated information on these dimensions. Charities may avoid this problem in two ways. First, for mass-media appeals, they may try to establish the demographic correlates of constructs such as belief in a just world (Witt 1989) and match these to audience profiles. Second, charities maintain some profiles on regular or new donors; these may be extended and refined to include information about the donor's motivations for helping and expectations regarding the consequences. Customizing the helping situation in this fashion may help charitable organizations practice relationship marketing (McCort 1993). Relationship marketing, with its focus on maintaining longterm relationships, may provide valuable guidelines to charities hoping to sustain reliable donor bases.

In studying helping behavior, marketers would be entering a new and challenging area (Goldberg 1994). Despite the challenges, however, the study of the help rendered to charitable organizations will have significant payoffs on several fronts. Charitable organizations are often the front line of defense against the myriad, growing problems of today's society-drugs, violence, AIDS, homelessness, and hopelessness, to name a few. By buttressing the efforts of charitable organizations, marketers may make the world a healthier and happier place (Andreasen 1993), not a mean accomplishment for any discipline or its practitioners.

\section{REFERENCES}

Aderman, David, Sharon Brehm, and Lawrence Katz (1974), "Empathic Observations of an Innocent Victim," Journal of Personality and Social Psychology, 29 (3), 342-47.
Allen, Chris T. (1982), "Self-Perception Based Strategies for Stimulating Energy Conservation," Journal of Consumer Research, 8 (March), 381-90. 
Allen, Jeff and Nick Maddox (1990), "Segmenting Blood Donors by Their Perceptions and Awareness About Blood Donations," Health Marketing Quarterly, 7 (1/2), 177-93.

— and Daniel D. Butler (1993), "Assessing the Effects of Donor Knowledge Risk on Intentions to Donate Blood," Journal of Health Care Marketing, 13 (3), 26-33.

American Association of Fund-Raising Counsel (1994), Giving USA. New York: American Association of Fund-Raising Counsel.

Andreasen, Alan R. (1993), “A Social Marketing Research Agenda for Consumer Behavior Researchers," in Advances in Consumer Research, Vol. 20, Leigh McAlister and Michael L. Rothschild, eds. Provo, UT: Association for Consumer Research, 1-5.

Bagozzi, Richard P. and David J. Moore (1994), "Public Service Advertisements: Emotions and Empathy Guide Prosocial Behavior," Journal of Marketing, 58 (January), 56-70.

Bandura, Albert (1983), "Self-Efficacy Determinants of Anticipated Fears and Calamities," Journal of Personality and Social Psychology, 45 (2), $464-469$.

Barr, Peter B., Dinesh S. Dave, Sammy Amin (1991), "Perceptual Attitudes of a Charitable Organization," Health Marketing Quarterly, 8 (3/4), 81-95.

Batson, Daniel C. (1987), "Prosocial Motivation: Is it Ever Truly Altruistic?" in Advances in Experimental Social Psychology, Vol. 20, L. Berkowitz, ed. New York: Academic Press, 65-122.

- (1991), The Altruism Question. Hillsdale, NJ: Lawrence Erlbaum Associates.

_- Janine L. Dyck, Randall Brandt, Judy A. Batson, Anne L. Powell, M. Rosalie McMaster, and Cari Griffith (1988), "Five Studies Testing Two New Egoistic Alternatives to the EmpathyAltruism Hypothesis," Journal of Personality and Social Psychology, 55 (1), 52-77.

Becker, Gary S. (1981), A Treatise on the Family. Cambridge, MA: Harvard University Press.

Bem, Darryl J. (1972), "Self-Perception Theory," in Advances in Experimental Social Psychology, L. Berkowitz, ed. New York: Academic Press, 1-62.

Berkowitz, L. (1972), “Social Norms, Feelings, and Other Factors Affecting Helping Behavior," in Advances in Experimental Social Psychology, Vol. 6, M. L. Berkowitz, ed. New York: Academic Press, 220-30.

Bies, Robert J. (1987), "The Predicament of Injustice: The Management of Moral Outrage," in Research in Organizational Behavior, Vol. 9, L. L. Cummings and B. M. Staw, eds. Greenwich, CT: JAI Press, 289-319.

Blockner, Joel, Beth Guzzi, Julie Kane, Ellen Levine, and Kate Shaplen (1984), "Organizational Fundraising: Further Evidence on the Effect of Legitimizing Small Donations," Journal of Consumer Research, 11 (June), 611-14.

Bloom, Paul N. and William D. Novelli (1981), "Problems and Challenges in Social Marketing," Journal of Marketing, 45 (Spring), 79-88.

Brehm, Jack W. (1966), A Theory of Psychological Reactance. New York: Academic Press.

Broadbridge, Adelina and Suzanne Horne (1994), "Who Volunteers for Charity Retailing and Why?" Service Industries Journal, 14 (4), 421-37.

Bruce, Neil and Michael Waldman (1990), "The Rotten Kid Theorem Meets the Samaritan's Dilemma," Quarterly Journal of Economics, 105 (1), 155-65.

- and - (1991), "Transfers in Kind: Why They Can Be Efficient and Non-Paternalistic," American Economic Review, 81 (5), 1345-51.

Burnett, John J. (1981), "Psychographic and Demographic Characteristics of Blood Donors," Journal of Consumer Research, 8 (June), 62-66. and Van R. Wood (1988), “A Proposed Model of the Donation Decision Process," in Research in Consumer Behavior, E. Hirschman and J. Sheth, eds. Greenwich, CT: JAI Press, 1-47.

Burnkrant, Robert E. and Thomas J. Page, Jr. (1982), “An Examination of the Convergent, Discriminant, and Predictive Validity of Fishbein's Behavioral Intention Model," Journal of Marketing Research, 19 (November), 550-61.

Cermak, Dianne S. P., Karen Maru File, and Russ Alan Prince (1994), "A Benefit Segmentation of the Major Donor Market," Journal of Business Research, 29 (2), 121-34.

Childers, Terry L. and Michael J. Houston (1984), "Conditions for a Picture-Superiority Effect on Consumer Memory," Journal of Consumer Research, 11 (September), 643-54.

Cialdini, R. B., R. R. Reno, and C. A. Kallgren (1990), “A Focus Theory of Normative Conduct: Recycling the Concept of Norms to Reduce Littering in Public Places," Journal of Personality and Social Psychology, 58 (6), 1015-26.

- M. Schaller, D. Houlihan, K. Arps, F. Fultz, and A. Beaman (1987), "Empathy-Based Helping: Is it Selfishly or Selflessly Motivated?" Journal of Personality and Social Psychology, 52, 749-58.

, J. E. Vincent, S. K. Lewis, J. Catalan, D. Wheeler, and B. L. Darby (1975), "Reciprocal Concessions Procedure for Inducing Compliance: The Door-in-the-Face Technique," Journal of Personality and Social Psychology, 31 (February), 206-15.

Clark, Margaret S. and Alice M. Isen (1982), "Toward Understanding the Relationship Between Feeling States and Social Behavior," in Cognitive Social Psychology, Albert H. Hastoef and Alice M. Isen, eds. New York: Elsevier North-Holland, 73-108.

Clary, Gil E. and Leslie Orenstein (1991), "The Amount and Effectiveness of Help: The Relationship of Motives and Abilities to Helping Behavior," Personality and Social Psychology Bulletin, 17 (1), 58-64.

Comte, I. Auguste (1851), System of Positive Polity. London: Longmans, Green.

Cunningham, M. R., J. Steinberg, and R. Greu (1980), "Wanting to and Having to Help: Separate Motivations for Positive Mood and Guilt-Induced Helping," Journal of Personality and Social Psychology, 38 (2), 181-92.

Danko, William D. and Thomas J. Stanley (1986), "Identifying and Reaching the Donation-Prone Individual: A Nationwide Assessment," Journal of Professional Services Marketing, 2 (Fall/Winter), 117-22.

Davis, Mark H. (1983), "Measuring Individual Differences in Empathy: Evidence for a Multidimensional Approach," Journal of Personality and Social Psychology, 44 (1), 113-26.

- (1994), "Helping and Empathy: Taking the Multi-Dimensional View," in Marketing Theory and Applications: American Marketing Association Winter Conference, C. Whan Park and Daniel C. Smith, eds. Chicago: American Marketing Association, 1.

- Jay G. Hull, Richard D. Young, and Gregory G. Warren (1987), "Emotional Reactions to Dramatic Film Stimuli: The Influence of Cognitive and Emotional Empathy," Journal of Personality and Social Psychology, 52 (1), 126-33.

Dawson, Scott (1988), "Four Motivations for Charitable Giving: Implications for Marketing Strategy to Attract Monetary Donations for Medical Research," Journal of Health Care Marketing 8 (June), 31-37.

Dovidio, John F., Judith L. Allen, and David A. Schroeder (1990), "Specificity of Empathy-Induced Helping: Evidence for Altruistic Motivation," Journal of Personality and Social Psychology, 59 (2), 249-60.

Eisenberg, Nancy (1986), Altruistic Emotion, Cognition, and Behavior. Hillsdale, NJ: Lawrence Erlbaum Associates.

Engel, James, Martin R. Warshaw, and Thomas C. Kinnear (1994), Promotional Strategy. Boston: Richard D. Irwin 
Fern, Edward F., Kent B. Monroe, and Ramon A. Avila (1986), "Effectiveness of Multiple Request Strategies: A Synthesis of Research Results," Journal of Marketing Research, 23 (May), 144-52.

Festinger, Leon (1954), “A Theory of Social Comparison Processes," Human Relations, 7, 117-40.

Fraser, Cynthia, Robert E. Hite, and Paul L. Sauer (1988), "Increasing Contributions in Solicitation Campaigns: The Use of Large and Small Anchor Points," Journal of Consumer Research, 14 (2), 284-87.

Freedman, J. L. and S. Fraser (1966), "Compliance Without Pressure: The Foot-in-the-Door Technique," Journal of Personality and Social Psychology, 4 (October), 195-202.

Fultz, J., M. Schaller, and R. B. Cialdini, (1988), "Empathy, Sadness, and Distress: Three Related but Distinct Affective Responses to Another's Suffering," Personality and Social Psychology Bulletin, 14 (2), 312-25.

Goldberg, Marvin E. (1994), "Social Marketing: Are We Fiddling While Rome Burns?" Presidential Address for the Society for Consumer Psychology.

Gouldner, A. W. (1960), "The Norm of Reciprocity: A Preliminary Statement," American Sociological Review, 25 (2), 161-79.

Greenberg, Jerald (1987), “A Taxonomy of Organizational Justice Theories," Academy of Management Review, 12 (1), 9-22.

Griffin, Mitch, Barry J. Babin, Jill S. Attaway, and William R. Darden (1993), "Hey You, Can Ya Spare Some Change? The Case of Empathy and Personal Distress As Reactions to Charitable Appeals," in Advances in Consumer Research, Vol. 20, Provo, UT: Association of Consumer Research, 508-14.

Guy, Bonnie S. and Wesley E. Patton (1989), "The Marketing of Altruistic Causes: Understanding Why People Help," Journal of Consumer Marketing, 6 (1), 19-30.

Harvey, James (1990), "Benefit Segmentation for Fundraisers," Journal of the Academy of Marketing Science, 18 (1), 77-86.

Heider, Fritz (1958), The Psychology of Interpersonal Relations. New York: John Wiley \& Sons.

Hoffman, M. L. (1984), "Interaction of Affect and Cognition in Empathy," in Emotions, Cognition, and Behavior, C. E. Izard, J. Kagan, and R. B. Zajonc, eds. Cambridge: Cambridge University Press, 41-63.

Horton, Raymond L. (1991), "Marketing the Concept of Becoming A Potential Organ Donor," Journal of Health Care Marketing, $11(3), 36-45$.

Hui, Michael K. and John E. G. Bateson (1991), "Perceived Control and the Effects of Crowding and Consumer Choice on the Service Experience," Journal of Consumer Research, 18 (2), 174-84.

Independent Sector (1994), Giving and Volunteering in the United States. Washington: Independent Sector.

Isen, Alice M. (1984), "Towards Understanding the Role of Affect in Cognition," in Handbook of Social Cognition, R. Wyer and T. Srull, eds. Hillsdale, NJ: Lawrence Erlbaum Associates. - and Alan Noonberg (1979), "The Effect of Photographs of the Handicapped on Donations to Charity: When a Thousand Words May Be Too Much," Journal of Applied Social Psychology, 9 (5), 426-31.

Kelman, Herbert C. (1961), "Processes of Opinion Change," Public Opinion Quarterly, 25 (1), 57-78.

Kotler, Philip (1979), "Strategies for Introducing Marketing into Non Profit Organizations,” Journal of Marketing, 43 (January), 37-44.

Kraut, Robert E. (1973), "Effects of Social Labeling on Giving to Charity," Journal of Experimental Psychology, 9 (6), 551-62.

Krebs, Dennis L. and Dale T. Miller (1985), "Altruism and Aggression," in Handbook of Social Psychology, Vol. 2, G. Lindzey and E. Aronson, eds. New York: Random House, 1-72.

Kuhn, Donald M. (1989), "Lapsed Donors Are Your Friends," Fundraising Management, 20 (6), 24-32.
Latane, Bibb (1981), "Psychology of Social Impact," American Psychologist, 36 (4), 343-56.

LaTour, Stephen A. and Ajay K. Manrai (1989), "Interactive Impact of Informational and Normative Influence on Donations," Journal of Marketing Research, 26 (August), 327-35.

Lerner, Melvin J. (1980), The Belief in a Just World: A Fundamental Delusion. New York: Plenum Press.

Luthans, Fred and Robert Kreitner (1985), Organizational Behavior Modification and Beyond: An Operant Social Learning Approach. Glenview, IL: Scott, Foresman.

Maddux, James E. and Melinda A. Stanley (1986), "Self-Efficacy Theory in Contemporary Psychology: An Overview," Journal of Social and Clinical Psychology, 4 (3), 249-55.

Margolis, H. (1982), Selfishness, Altruism, and Rationality. Cambridge: Cambridge University Press.

Martin, Mike W. (1994), Virtuous Giving: Philanthropy, Voluntary Service, and Caring. Bloomington, IN: Indiana University Press.

McCort, J. Daniel (1993), “A Framework for Evaluating the Relational Extent of A Relational Marketing Strategy in Non-Profit Organizations," in Marketing Theory and Applications: American Marketing Association Winter Conference, Rajan Varadarajan and Bernard Jaworski, eds. Chicago: American Marketing Association, 409-33.

Meyers-Levy, Joan and Durairaj Maheswaran (1992), "When Timing Matters: The Influence of Temporal Distance on Consumers' Affective and Persuasive Responses," Journal of Consumer Research, 19 (3), 424-33.

Mills, Richard T. and Davis S. Krantz (1979), "Information, Choice and Reactions to Stress: A Field Experiment in a Blood Bank With Laboratory Analogue," Journal of Personality and Social Psychology, 37 (4), 608-20.

Mindak, William A. and H. Malcolm Bybee (1971), "Marketing's Application to Fund Raising," Journal of Marketing, 35 (July), 13-18.

Mitchell, Herman E. and Donn Byrne (1973), "The Defendant's Dilemma: Effects of Jurors' Attitudes and Authoritarianism on Judicial Decisions," Journal of Personality and Social Psychology, 25 (1), 123-29.

Moore, Ellen M., William O. Bearden, and Jesse E. Teel (1985), "Use of Labeling and Assertions of Dependency in Appeals for Consumer Support," Journal of Consumer Research, 12 (June), 90-96.

Omoto, Allen and Mark Snyder (1989), "Basic Research in Action: Volunteerism and Society's Response to AIDS," Personality and Social Psychology Bulletin, 16 (1), 152-65.

Pessemier, Edgar A., Albert C. Beamon, and Dominique M. Hanssen (1977), "Willingness to Supply Human Body Parts: Some Empirical Results," Journal of Consumer Research, 4 (December), 131-40.

Piliavin, J. A. and P. L. Callero (1990), Giving the Gift of Life to Unnamed Strangers. Baltimore: Johns Hopkins University Press.

_ and Hong-Wen Charng (1990), "Altruism: A Review of Recent Theory and Research," in Annual Review of Sociology, Vol. 16, W. R. Scott and J. Blake, eds. Palo Alto, CA: Annual Reviews, 27-65.

$\longrightarrow$, J. F. Dovidio, S. L. Gaeitner, and R. D. Clark (1981), Emergency Intervention. New York: Academic Press.

Reingen, Peter H. (1978), "On Inducing Compliance With Requests," Journal of Consumer Research, 5 (September), 96-102.

- (1982), "Test of a List Procedure for Inducing Compliance With a Request to Donate Money," Journal of Applied Psychology, 67 (1), 110-18.

Riecken, Glen and Ugur Yavas (1986), "Seeking Donors Via Opinion Leadership," Journal of Professional Services Marketing, 2 (1/2), 109-16. 
Rothschild, Michael L. (1979), "Marketing Communications in Nonbusiness Situations or Why It Is So Hard to Sell Brotherhood Like Soap," Journal of Marketing, 43 (Spring), 11-20.

Sameulson, Paul A. (1993), "Altruism as a Problem Involving Group Versus Individual Selection in Economics and Biology," American Economic Review, 83 ( 2), 143-48.

Schachter, S. (1959), The Psychology of Affiliation. Stanford, CA: Stanford University Press.

Schibrowsky, John A. and James W. Peltier (1995), "Decision Frames and Direct Marketing Offers: A Field Study in a Fundraising Context," Journal of Direct Marketing, 9 (1), 8-16.

Schlegelmich, Bodo B., A. Diamantopoulos, and A. Love (1992), "Determinants of Charity Giving," Marketing Theory and Applications: American Marketing Association Winter Conference, Chris T. Allen et al., eds. Chicago: American Marketing Association, 507-16.

- and A. C. Tannin (1989), "Market Segment-Oriented Fund-Raising Strategies: An Empirical Analysis," Marketing Intelligence and Planning, 7 (11), 16-24

Scott, C. A. (1978), "The Effects of Trial and Incentives on Repeat Purchase Behavior," Journal of Marketing Research, 13 (August), 263-69.

Sharpe, Robert F. (1987), "Helping People Give What They Want, and When," Fundraising Management, 17 (12), 90+.

Shelton, Suzanne H. (1990), "Developing the Construct of General Self-Efficacy," Psychological Reports, 66 (3), 987-94.

Sherry, John F. (1983), "Gift Giving in Anthropological Perspective," Journal of Consumer Research, 10 (September), 157-68.

Simmons, Roberta G., S. K. Marine, and R. L. Simmons (1987), Gift of Life: The Effect of Organ Transplantation on Individual, Family and Societal Dynamics. New Brunswick, NJ: Transaction Books.

Simon, Herbert A. (1993), "Altruism and Economics," American Economic Review, 83 (2), 156-61.

Smithson, Michael, Paul R. Amato, and Philip L. Pearce (1983), Dimensions of Helping Behaviour. Oxford: Pergamon Press.

Soukop, David J. (1983), "A Markov Analysis of Fund-Raising Alternatives," Journal of Marketing Research, 20 (3), 314-19.
Squires, Con (1992), “Don't Let Your Donors Go Without a Fight," Fundraising Management, 23 (4), 55-56.

Stark, Oded (1989), "Altruism and the Quality of Life," American Economic Review, 79 (2), 86-90.

Stayman, Douglas M. and David A. Aaker (1988), "Are All the Effects of Ad-Induced Feelings Mediated by A-Ad?" Journal of Consumer Research, 15 (3), 368-73.

Swinyard, William R. and Michael L. Ray (1977), “AdvertisingSelling Interactions: An Attribution Theory Experiment," Journal of Marketing Research, 14 (Winter), 22-32.

Thornton, Bill, Gayle Kirshner, and Jacqueline Jacobs (1991), "Influence of a Photograph on a Charitable Appeal: A Picture May Be Worth a Thousand Words When It Has to Speak for Itself," Journal of Applied Social Psychology, 21 (6), 433-45.

Tybout, Alice M. and Richard F. Yalch (1980), "The Effect of Experience: A Matter of Salience?" Journal of Consumer Research, 6 (March), 406-13.

Tyler, Tom R. (1994), "Psychological Models of the Justice Motives: Antecedents of Distributive and Procedural Justice," Journal of Personality and Social Psychology, 67 (5), 850-63.

Varadarajan, P. Rajan and Anil Menon (1988), "Cause Related Marketing: A Coalignment of Marketing Strategy and Corporate Philanthropy," Journal of Marketing, 52 (July), 58-74.

Wilson, John P. and Richard Petruska (1984), "Motivation, Model Attributes, and Prosocial Behavior," Journal of Personality and Social Psychology, 46 (2), 458-68.

Witt, L. Alan (1989), "Urban-Nonurban Differences in Social Cognition: Locus of Control and Perceptions of a Just World," Journal of Social Psychology, 29 (5), 715-17.

Yavas, U., G. Riecken, and E. Babakus (1993), "Efficacy of Perceived Risk as a Correlate of Reported Donation Behavior: An Empirical Analysis," Journal of the Academy of Marketing Science, 21 (1), 65-70.

Zuckerman, M., M. Lazzaro, and D. Waldgeir (1979), "Undermining Effects of Foot-in-the-Door With Extrinsic Rewards," Journal of Applied Social Psychology, 9 (3), 292-96. 
Copyright of Journal of Marketing is the property of American Marketing Association and its content may not be copied or emailed to multiple sites or posted to a listserv without the copyright holder's express written permission. However, users may print, download, or email articles for individual use. 